\title{
The impact of research results on art education
}

\section{Impacto de los resultados de investigaciones en la enseñanza artística}

\author{
JUAN-CARVAJAL, Mara Liobał, JUAN-CARVAJAL, Dargen Tania, VDOVINA, María \\ Universidad Autónoma de Zacatecas, Zacatecas, México; Universidad de las Artes, La Habana, Cuba; Universidad \\ Autónoma de Zacatecas, Zacatecas, México
}

ID $1^{\text {st }}$ Author: Mara Lioba, Juan-Carvajal / ORC ID: 0000-0001-6968-3813, Researcher ID Thomson: P-7756-2016, CVU CONACYT ID: 216443

ID $1^{\text {st }}$ Co-author: Dargen Tania, Juan-Carvajal / OCR ID: 0000-0002-8281-8169, Researcher ID Thomson: V-7816-2019

ID $2^{\text {nd }}$ Co-author: María, Vdovina / ORC ID: 0000-0001-6656-0789, Researcher ID Thomson: S-7917-2018

DOI: $10.35429 / J P D .2021 .14 .5 .1 .9$

Received July 25, 2021; Accepted December 30, 2021

\begin{abstract}
Music teaching today represents a greater effort compared to previous eras. Before, quality and rigor, combined with ideas, resources, techniques and emotions were shared, inside or outside of the school environment. Currently, the same process is accelerated: the considerable number of research in, about and in favor of art, joined with technological impact, and the existence of social networks, activates informational exchange, and causes contrasts that require higher creativity from the teacher in order to offer tools for the student to qualify the cumulus of information at their grasp. This is made possible by integrating teaching with research, a popular theme in education-related events; which constitutes the objective of this work: to popularize alternatives for the achievement of the possibilities the research process offers in music teaching. The analytic-sinthetical metod, the life history method, documental analysis method and interview were combined from a qualitative standpoint, which was conducive to a multilateral study of the composer and his creativity's developmemt, and also to the activities' design, and the search for information. Ideas and experiences about the potential of research for art education, plus extracurricular activities designed and based on the research are therefore offered.
\end{abstract}

Research process, Art education, Research methods

\section{Resumen}

La enseñanza artística en la actualidad conlleva un esfuerzo superior respecto a siglos anteriores. Antes, calidad y rigor, se conjugaban con ideas, recursos, técnicas y emociones dentro y fuera del contexto escolar. Actualmente el proceso se acelera por el número considerable de investigaciones en, sobre, y para el arte, unido al impacto tecnológico y a la existencia de redes sociales que activan el intercambio informativo, provocan contrastes, y exigen del profesor mayor creatividad para ofrecer al estudiante, herramientas que le permitan diferir el cúmulo de información a su alcance. Esto es posible al integrar docencia e investigación, tema recurrente en eventos sobre educación, lo que motiva el objetivo de este trabajo: generalizar alternativas para el aprovechamiento de las potencialidades que ofrece el proceso investigativo en la enseñanza de la música. Desde un enfoque cualitativo se combinaron los métodos analítico-sintético, historia de vida, análisis de documentos y entrevista, lo que propició el estudio multilateral del desarrollo del compositor y de su creación, el diseño de actividades y la búsqueda de información. Se brindan ideas y experiencias sobre el potencial de las investigaciones para la enseñanza artística y actividades extracurriculares diseñadas a partir de los resultados de la investigación.

Proceso investigativo, Enseñanza artística, Métodos de investigación

Citation: JUAN-CARVAJAL, Mara Lioba, JUAN-CARVAJAL, Dargen Tania, VDOVINA, María. The impact of research results on art education. Journal Practical Didactics. 2021, 5-14: 1-9

$\uparrow$ Researcher contributing as first author. 


\section{Introduction}

The teaching profession in higher education is permeated by globalization and by the swift scientific, technical and social development, which in terms of communication impacts the educational system. Consequently, it is characterized by a dynamism that entails a greater effort than in previous centuries.

The organization by disciplines or modules of the framework that disclosed the features of the profession, and the resources that ensured the development of a curriculum, along with the specialization of the teacher, certified the quality and rigor of the professional's training. At present, the process is accelerating and the technological impact causes discrepancies that demand from the teacher familiarity with tools that foster creativity and promote guided motivation towards study in the pupil, at the same time as these references are examined, in order to compare and make the most appropriate decisions, taking into account the beffiting context.

The use of technologies in education is abundant and rigorous; the trend is progressing towards technological availability in any of its variants: consumer technology (tools created for recreational or professional purposes); digital strategies (to improve the teachinglearning process); internet technologies (a potential available to all, online tools that complement the process); educational technologies (specifically designed for teaching); or technologies in social networks (Johnson, Estrada and Freeman, 2014). Its use, increasingly widespread in society, greatly impacts teaching.

Art education in general, like any educational process, also absorbs the infinite possibilities provided by the benefits offered by information technology and communications. Among the benefits this supplies higher education with, there could be mentioned: an easy access to information, available variability, high speed parameters during its processing, elimination of local space and time barriers, possibility of feedback and interactivity, creation of flexible learning spaces, optimization of educational-research activities, and speed in process management (Gómez, Contreras, \& Gutiérrez, 2016).
The ease of traveling through time through artistic, architectural, and visual representations, or for example, in the case of music, recordings, favors the characterization of the moment that is recreated and offers observation, listening, comparison and development in imagination to art education; all of these being motivating elements to create which, accompanied by theoretical support, streamline the teaching process and take advantage of the wide spectrum of information available to the student.

Undoubtedly, the exploitation of the existing informational potential depends to a great extent on the preparedness of the teacher. The multidisciplinarity in knowledge management, coupled with stimulation of the student's motivation, requires a pedagogical mastery from the teacher or tutor; in other words, it is necessary to acquire a cultural background that allows them to make comparisons based on indicators that refer to aspects of territoriality, tradition, time, forms or methods, so that the necessary competencies for professional practice are developed. Likewise, when managing their lesson, the teacher must explore professional problems, solutions, experiences and good practices, in accordance with the particularities of the branch of art to which they belong.

This course of action is informed by the benevolent intention of cultivating the benefits of researtch to impact the quality of the lessons. The modeling of the content stated in the programs of the disciplines or subjects, along with the knowledge of the socio-economic particularities, of the historical, cultural, the traditional, the classical and the popular angles, confers a vision of the old and how it has evolved towards the present. It is there where there is a wealth of information available for the teacher to integrate the teaching and research processes through which, consequently, a positive impact is achieved in artistic teaching.

Research in art changes the sense of perception, transforms the researcher in such a way that it is impossible for him to listen to, criticize or perform an artistic work again, without a study that encompasses the universality of what can be appreciated in it. (Sánchez, Juan-Carvajal, Vdovina, and JuanCarvajal, 2016, p. 102) 
It is precisely this universality that is the greatest potential the teacher has for the lessons, its exploitation helps the student's motivation to seek information and investigate, which are aspects that contribute to the benefit of the disciple and the teacher himself as a feedback system in their academic labor.

Motivation is based on the needs of the individual. If we could have a good characterization of the student and could take advantage of the potentialities of the context, emotional and cognitive processes that fuel curiosity towards the unknown can be developed. In art, particularly in teaching a musical instrument, differentiated work with students has greater advantages; in this profession, the teacher becomes a tutor who accompanies his students in most of his career if not in all of it, which enables the generation of new needs in his disciples.

The teacher is a permanent supplier of knowledge, discoveries and affirmations that contribute to the fact that, when the artists reveal themselves to the public, they manifest their innate talent, revealing their capacity and expressive nature. Experience has shown that characterizing the student is not an easy task, since it involves inquiring into his personality traits. Consequently, pedagogical observation will be present in all educational activity so as not to lose sight of the details that point to what to work on with each of the applicants so that they gain confidence and guide them towards success.

An alternative in this sense is attention and transmission of previous positive experiences, both one's own and those of other people: moral support on the basis of narration of anecdotes, stimulation by taking advantage of the acquired knowledge, or sharing of a vision based on the possibility of carrying out the projected target until the goals are achieved, make a frustrating situation feasible for redesign and for greater effort be put forth to achieve the intended purpose. A teacher who is able to integrate both the teaching and research processes and take advantage of the impact of the latter in teaching, has a greater chance of achieving success with his students.
Determining the impact of the research process in the classroom is discerned from different points of view; in general, the socalled "impact measurement" goes through the comparison of moments based on specific indicators such as, the fulfillment of objectives, judgment of the value of the process, or the issuance of a value judgment that facilitates decision-making. However, the impact is not always related to a result, its action will be latent throughout the investigative process:

Impact apprisal is a type of evaluation that can be carried out in the final phase of the intervention of a policy, program or project, or in its intermediate phase, in order to make decisions about its continuation, and possible adjustments which would be necessary. There is a certain consensus in which an impact evaluation is defined as the measurement of the changes in the well-being of the individuals participating in the program, and which could be attributed to it.

... An impact evaluation aims to measure the effect that any program may have on some variable associated with the well-being of its beneficiaries. (Estacio, Millán, Olivera, Parra and Santa María, 2010, p.6)

On the other hand, the impact is observed in different ways, despite the recurring criteria of change and its influence when making decisions. In its evaluation, four potential advantages are perceived: the demonstration, given by the possibility of presenting evidence of a result or, of the acting guidelines during a process; orientation, since it favors the cosmopolitan vision of context, characterization of an object, projection and prevention; motivation, which is related to the first two and encourages action and innovation; and the integrative element, which offers tools to bring together or unite processes, results, modes, etc., which favors decision-making and proactive positions in the pedagogical process.

Evaluating the impact is not precisely the objective proposed in this work, but instead it is the usefulness of its results, fundamentally those of the application of research methods, to complement the work of the music teacher. Consequently, alternatives are provided here for taking advantage of the potential offered by this process in artistic teaching, particularly in music, in the teaching (and learning) of an instrument.

JUAN-CARVAJAL, Mara Lioba, JUAN-CARVAJAL, Dargen Tania, VDOVINA, María. The impact of research results on art education. Journal Practical Didactics. 2021 


\section{Development of an idea}

According to the various bibliographic sources consulted, the first moment of the investigative process is the generation of the "idea"; an idea that, without any precision, allows you to visualize a goal and identify a number of problems that affect the proper functioning of a process or object. In artistic education, particularly in music, there is a number of works with several centuries of existence in the catalog, composed, for example, for bowed string instruments. In this way, there is a wide spectrum of works accumulated by humanity.

However, despite the efforts of educational centers and technological advances and library exchanges, it is impossible for each educational institution to find all this wealth. However, concerned about the absence of scores, specialized articles, recordings, videos, or references about composers with less dissemination, recent musicological research and contemporary creation in numerous territorial areas keeps the processes of musical research active, which could be the object of motivation for the study, approach and a local, national and international dissemination of new repertoires for chordophones. So, why not take advantage during instrument lessons, and learn the repertoire to interpret, of the results of those investigative processes that compile such information?

There is research that promotes, -to mention a daily practice-, the study of cases or life history as scientific methods to reveal the characteristics of a time, a work or a certain author. Traits such as knowledge of the context, historical moment, personality, social importance, influence of other regions or times, or existing technological resources, among others, have been generated from its contributions. In the case of teaching an instrument, all this allows the student to understand why a specific approach to a work should be different from another, not only from a technical point of view but also from an interpretive point of view (final objective); for this reason, it is necessary to know why a musical composition differs from another even if it is by the same author and shares certain stylistic features; or why in harmony dissimilar structures are drawn and that according to their links or chord arrangement, particularities of an artistic movement, trend or epoch are manifested.
Also, its important to consider the character, and the melodic sense and phrasing in the performance, to understand why the interpreters put a personal.

Although these would not be the scientific questions to be asked during an investigation whose purpose is the achievement of an academic degree, the results obtain are justified to be presented to the students in order to stimulate the search for information oriented towards the corresponding program to your resume. This will provide, in addition to culture, a coherent and convincing sense of the musical interpretation that is made, i.e., a personal codification of the expressive language that is transmitted to the listener.

It is necessary to mean that the selection of works or composers that students must work on will correspond to the curriculum for the training of the musician, the level at which they are and the discipline or subject they are studying. However, greater effect will be achieved if this is complemented with a previous or parallel characterization of the work, carried out by the students themselves.

\section{Methodology}

\section{From research to performance, and viceversa}

The line of study of various contemporary works pursued with academic, investigative and / or interpretive purposes, led at a certain stage,with a greater or lesser degree of involvement the authors of this work to results that focused on the musical production for bowed string instruments in Cuba, which entailed the study of diverse compositions written in a specific period and the characteristics of the composers who were formed or grew up in said period; this simplified the process they had to exercise during they performance as teachers. 
At a certain point, once this process was completed, which included publishing a book and the recording of two compact discs ${ }^{1}$, some students became interested in interpreting certain works collected for the first time in these compilations; So it was time to reveal to the students that:

(...) Musical language does not pretend anything but communication through a varied proposal, an opening of codes through which the composer rejoices in showing his own personality and telling what is given to him in an authentic way. This is how the understanding of the musical work can only occur through a socio-historical and cultural analysis of the individual, his environment and his field of action. (Juan-Carvajal and JuanCarvajal, 2014)

This position implies the positive presence of a complicity between the music teacher and the student since, in the training process, not only the instrumental or technical aspects are affected, but the spiritual one is awakened. An aesthetic sense is developed from which judgments, tendencies, techniques, characteristics, identity traits, analysis and evaluations of the positioning in the face of certain constituent structural elements of a composition emerge and are evaluated, or it might be that emotional states are identified that denote feelings, sensations and expressions present in the (supposedly spontaneous) interpretation of the signs in a score, during the performance of a musical work.

(...) The sensation that is produced when contemplating, listening or transmitting a performance creates an inexplicable state due to the lack of communication between the evoking language (signic) and the spoken language with which we communicate.

\footnotetext{
${ }^{1}$ The book Bowed Strings in Cuba. Half a century of creation written by Dr.C. Mara Lioba Juan-Carvajal and Dr.C. Dargen Tania Juan-Carvajal with the collaboration of Dr.C. María Vdovina in 2014, published by the CIDMUC publishing house of Cuba and CDs I and II Contemporary Music for Viola, production made with PRODEP resources, produced at the Autonomous University of Zacatecas, Mexico, 2017, and recorded by the teaching violists Mara Lioba Juan-Carvajal and María Vdovina, having as guests the Russian-American violist Viera Borisova, and the violinist and violist Alexander Vdovin.
}

This is how consciously or unconsciously we are looking for the explanation of the sensations. (Vdovina, 2010, p. 65).

Another idea is to ensure access to information with an orienting guideline that favors the search and the design of spaces for meditations on the characterization and execution of the works (or parts of them).

A positive experience has been fostering debate about the results achieved by students of the same level; a debate that could be particularly intentional towards the aspects in which some kind of difficulty could be considered to have existed. This activity would be divided by themes, which would be specified from the outset of preparing the activity, considering the characteristics of the student body or the selected composer (figure 1).

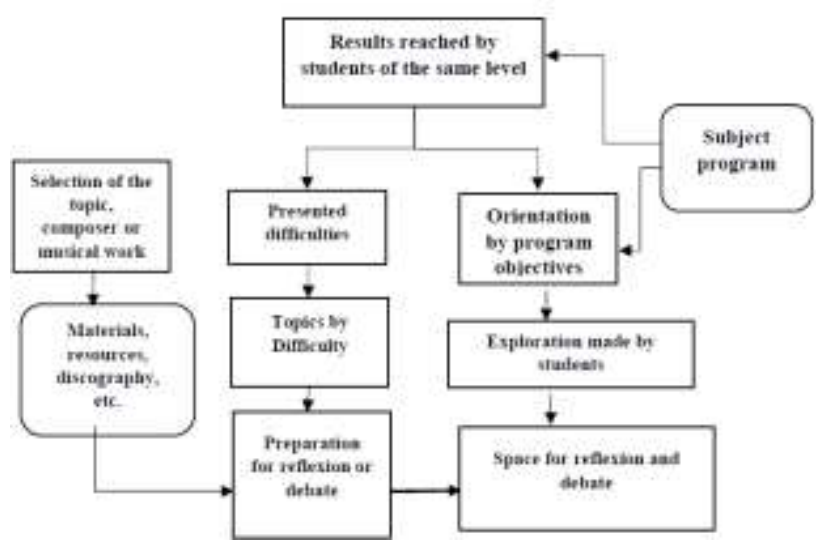

Figure 1 Flowchart exemplifying the preparation process of a debate

Source: Author's own elaboration

In the aforementioned research on bowed string instruments in Cuba, five composers who have passed through the Cuban reality during the last half century and who continue to compose were studied. All of them have a generational coincidence that makes it interesting to recognize the particularities of their ways of composing, their techniques, styles, periods, sources of inspiration, and expressive languages. Among their extensive and varied creations are recognized musical works for stringed instruments in different formats. A distinctive characteristic is that, alongside with composition, all of them perform (or they have done so at some stage of their lives) in other areas of artistic-musical knowledge such as orchestral conducting and / or teaching.

JUAN-CARVAJAL, Mara Lioba, JUAN-CARVAJAL, Dargen Tania, VDOVINA, María. The impact of research results on art education. Journal Practical Didactics. 2021 
An example of this particularity is evidenced in the professor, conductor and composer Jorge López Marín (Havana, 1949). $\mathrm{He}$ graduated from the Kiev Conservatory and, subsequently, conducted postgraduate studies in Moscow during the geopolitical period of the USSR. Marín is a Doctor of Arts in Sciences from the University of the Arts of Cuba (ISA) and works as a professor of orchestration, composition and orchestral conducting at the aforementioned university. His characterization made it possible for our students, who have known or performed his works, to observe the impact of foreign schools on his training and to verify the most genuine Cuban music in his creations.

\section{Benefits of research results for art education}

Chiefly, in order to characterize the studied composer, his creation and the influence the context and the historical period had on his work, the analytic-synthetical and life history methods were used. Given the peculiarities of his profession, the correlation between the technological, instrumental, historical and affective aspects necessary for the formation of the artist, has a greater likelihood of a bigger scope when the results of different research methods and techniques are combined and contrasted. The use of these methods provided a more thorough vision of the quirks of the composer and an increase, dosage and variance of the activities with the students.

The analytic-synthetical method has as a function the study, independently, of the various parts of the object (considered as a whole) to get to the knowledge of its regularities, developmental rules, relationships, and to later integrate that information, in order to generate new points of view or theories.

The possibility offered by this method, of breaking down the research into different parts, favored the design of a methodological strategy that fostered the multilateral analysis of the composer's development and his creation, and simplified the examination of aspects related to the objectives of the training of the bowed string instrumentalist.
In this case, the following aspects were examined: the formation of the composer, the stylistic tendencies according to the stages studied, as well as the local and universal contexts, and additionally, the peculiarities in the musical morphological structure, that is, attention was paid through observation, reflection and analysis of various elements among which melody, harmony, rhythm, instrumentation, etc. were assorted, in other words, everything that is perceived and expressed in contact with the audience when executing a musical performance.

Another proposal is to stimulate the development of values in the education of the student. This is done through a multidisciplinary analysis of the contexts of formation and development of the composer, of the particularities of their time and of how much and of how much and in which way this impacted on their creation. As a result, the art student is favored with an aesthetic and cultural recognition of a given era; in turn, they situate themselves with greater responsibility towards their formation and stimulate a sense of belonging, which allows them to transform knowledge into an idea or artistic expression: musical performance in the broadest sense of the concept.

Life history, like all qualitative research, has a strong interpretive component; its function is aimed at the elaboration of "(...) memories based on the collection of particularities in cultural practices rooted in traditions that can be erased over time; in other words, prepare documents that in one way or another preserve cultural identity" (JuanCarvajal and Juan-Carvajal, 2019, p.130).

Compliance with a methodological strategy for its application depends largely on the situation and the possibility of data collection. As a research method, it reveals the information mostly on account of individual or collective discourses, although bibliographic and documentary exploration and observation are not to beruled out.

Memories and experiential impressions are fundamental axes of a method that focuses on personal or collective experience and “(...) takes into consideration the affective meaning of things, situations, experiences, and relationships that affect people (... )" (Charries, 2012, p. 51).

JUAN-CARVAJAL, Mara Lioba, JUAN-CARVAJAL, Dargen Tania, VDOVINA, María. The impact of research results on art education. Journal Practical Didactics. 2021 
Its flexibility and possibility of representing the object as it is described gives it a certain degree of complexity when recounting the phenomena according to the memories of the protagonists or experts, which are sometimes divergent. In the research carried out, the methodological strategy integrated the documentary analysis and the interview.

The documentary analysis consists of the exploration of any object that registers some phenomenon - either in printed or digital format. The impact of the results of the research process offers the teacher information about the peculiarities of the object under study, which makes it possible to design and carry out various activities alongside the students based on the results obtained.

\section{Results}

The research process' results gave birth to the idea of designing activities where students fulfilling the objectives of the class was promoted, taking advantage of the impact the results of the application of the method brought, in order to promote motivation for study and creativity. Returning to the aforementioned composer, table 1 shows some of the works written by Jorge López Marín for different combinations of strings, strings with piano, or with other instruments (as a result of the application of the documentary analysis) with design ideas for activities made to work with students in different non-teaching spaces.

\begin{tabular}{|l|l|l|}
\hline \multicolumn{2}{|c|}{ Work Aormat } & \multicolumn{2}{c|}{ Activity design } \\
$\begin{array}{l}\text { Variaciones en } \\
\text { ritmos cubanos } \\
(1973)\end{array}$ & String quartet & $\begin{array}{l}\text { Aesthetical and stylistic } \\
\text { analysis in the context of } \\
\text { postmodernity in music. }\end{array}$ \\
\hline $\begin{array}{l}\text { Música para } \\
\text { viola y cuerdas } \\
\text { "Federico Smith } \\
\text { in memoriam" } \\
\text { (1977) }\end{array}$ & $\begin{array}{l}\text { Soloist viola string } \\
\text { and } \\
\text { (also written } \\
\text { for viola and } \\
\text { piano) }\end{array}$ & $\begin{array}{l}\text { Melodic and harmonic } \\
\text { analysis from different } \\
\text { performances taking into } \\
\text { account the educational } \\
\text { environment and the } \\
\text { characteristics of the } \\
\text { performer. }\end{array}$ \\
\hline $\begin{array}{l}\text { Musipaz (1988) } \\
\text { orchestra }\end{array}$ & $\begin{array}{l}\text { String } \\
\text { the feading with a debate about } \\
\text { and the impact of the } \\
\text { context on which it was } \\
\text { inspired (a sculpture). } \\
\text { The great expressivness of a } \\
\text { neoclassical-style-language. }\end{array}$ \\
\hline $\begin{array}{l}\text { Noche de tango } \\
(1999)\end{array}$ & $\begin{array}{l}\text { Pianoforte } \\
\text { and string } \\
\text { orchestra }\end{array}$ & $\begin{array}{l}\text { Listening and recognition of } \\
\text { the usual features of the } \\
\text { genre, mixed with } \\
\text { contemporary composition } \\
\text { techiques as well as poetry, } \\
\text { tango and afro-cuban } \\
\text { miscegenation. }\end{array}$ \\
\hline
\end{tabular}

\begin{tabular}{|c|c|c|}
\hline $\begin{array}{l}\text { Sweet Ceci Mar } \\
(2002)\end{array}$ & $\begin{array}{l}\text { Clarinet, } \\
\text { viola and } \\
\text { pianoforte }\end{array}$ & $\begin{array}{l}\text { Debate about the used } \\
\text { format, which includes a } \\
\text { wind instrument, -the } \\
\text { clarinet- and this } \\
\text { instruments' closeness with } \\
\text { the viola, the structure of } \\
\text { the work employed by } \\
\text { Mozart, and the influence } \\
\text { on the context of chamber } \\
\text { music and the development } \\
\text { of the viola on this genre. }\end{array}$ \\
\hline $\begin{array}{l}\text { Tangueando con } \\
\text { tumbao (2005) }\end{array}$ & \begin{tabular}{|l|} 
Pianoforte \\
and string \\
orchestra
\end{tabular} & $\begin{array}{l}\text { Reflexion about the use of } \\
\text { the chordophones, and the } \\
\text { perception of rhythmic and } \\
\text { melodic motives of popular } \\
\text { music. }\end{array}$ \\
\hline $\begin{array}{ll}\text { Rumor } & \text { de } \\
\text { Fantasmas } & \\
(2005) & \end{array}$ & \begin{tabular}{|l} 
String \\
orchestra
\end{tabular} & $\begin{array}{l}\text { Analysis of the postmodern } \\
\text { aesthetics that generally } \\
\text { characterize the composer's } \\
\text { music. }\end{array}$ \\
\hline $\begin{array}{l}\text { La danza } \\
\text { implacable } \\
\text { (2007) }\end{array}$ & Viola trio & $\begin{array}{l}\text { Concert-debate, with the } \\
\text { presence of specialists, } \\
\text { about the sound and } \\
\text { possibilities of the } \\
\text { instrument in a sui generis } \\
\text { organization: the viola trio. }\end{array}$ \\
\hline $\begin{array}{l}\text { Suite alegórica, } \\
\text { para piano y } \\
\text { violín (2009) } \\
\text { también en } \\
\text { versión para } \\
\text { violín y orquesta } \\
\text { de cuerdas. }\end{array}$ & $\begin{array}{l}\text { Violin and } \\
\text { pianoforte, or } \\
\text { soloist violin } \\
\text { and string } \\
\text { orchestra }\end{array}$ & $\begin{array}{l}\text { Appreciation of the } \\
\text { characteristics of the } \\
\text { composer concerning the } \\
\text { treatment of the violin as a } \\
\text { solo instrument, which } \\
\text { influenced the creation of } \\
\text { subsequent violin and } \\
\text { orchestra concertos. }\end{array}$ \\
\hline
\end{tabular}

Table 1 A simple of works written by Jorge López Marín for strings and/or combined with other instruments Source: Author's own elaboration

The possibility of open and intentional communication in the activities carried out based on the debate proposals, increased the students' motivation towards searching for comparing new sources, especially for moments of exchange with specialists and composers.

The compilation that resulted, enabled the students to become acquainted with the composer's works written for the formats where the bowed string instruments stand out, helped pinpointing the location and offered a possibility of reading and analyzing some scores.

López Marín's discography includes works for symphony orchestra, chamber ensembles or small formats. Regarding the bowed strings instruments, he wanders through different genres and styles, a fact which motivated listening and debate about the performances and a characterization of the different ways of approaching the work and performing it. 
The interview, as a recurring complementary method in life history research, enriches theoretical evaluations and motivates the search for new notions that support interpretive practice. Given the peculiarity of being in direct dialogue with the interlocutor, attention to verbal and extraverbal language is made easier. Its execution logic starts from the definition of the objectives and the identification of the aspects on which information is needed. Its arrangement requires the determination of the ideas or topics to be discussed - a guidance that is provided in advance - and a prior study to conduct it with dynamism and not lose the interest of the interviewee.

An essential element in the interview is the selection of the informants. In this sense, those who have knowledge and experience, possess the ability to reflect, can express themselves clearly, and are willing to provide information are recommended.

In general, the results of the exercise of combining the analytic-synthetical and life history methods, along with the sources' potential used by students for exploration, allow the design of activities such as round tables, panels or workshops, where the exchange between the protagonists of the events, the specialists or experts and the students is encouraged, which, in turn, arouses their interest to improve themselves to enhance their performance, either in classes in front of the teacher or tutor, or in front of the public.

The results of the application of research methods constitute a wealth of sources for the music teacher's work such as: knowledge of the subject, prestige and social impact of a composer; the characterization of compositions, especially in the case of contemporary and last century music, that can be exploited in order to raise the motivation of students towards the study and search of audiovisual products, musical performances, or production where the distinctive features of the works and their composers are highlighted, as well as the particularities of the region and the educational institution where the studies are carried out.

\section{Conclusions}

The technological development achieved by society has an impact on higher education with benefits such as the wide access and variability of information that, in turn, generate contradictions in the student. As a consequence, the teacher is required to improve their pedagogical mastery in order to develop a quality teaching process and the promotion of creativity and motivation towards study. An alternative for these demands is manifested in the integration of the research and teaching processes.

To obtain positive results during the use of the investigative potential in the artist's training, the teacher must profile the student and promote exploration and research on topics that develop their interest and are in correspondence with the objectives of the study plan of the career.

The use of the results of the research process in the artist's training derives in the search for technical information and a multidisciplinary vision of the evolution of art and, consequently, of individual and collective cultural development, as well as responsibility in their formative process, and their identity with the school and the territory.

The combination of methods and the comparison of the results obtained in the different stages of the investigation, complements the technological, instrumental and emotional aspects, and favors the design of educational tasks that promote in music students sensitivity, creativity and motivation towards study.

\section{References}

Chárriez, M. (diciembre de 2012). Historias de vida: una metodología de investigación cualitativa. Revista Griog, 5(1), 50-67.

Estacio, A., Millám, N., Olivera, M., Parra, M. y Santa María, M. (2010). Evaluación de impacto de dos programas de formación del Sena: formación de técnicos y tecnológicos y formación especializada del recurso humano vinculado a las empresas. Working paper (52). Centro de investigación económico y social. http://www.repository.fedesarrollo.org.co/handl e/11445/243 
Gómez, M.E., Contreras, L., y Gutiérrez, D. (mayo-agosto de 2016). El impacto de las tecnologías de la información y la comunicación en estudiantes de ciencias sociales: un estudio comparativo de dos universidades públicas. Innovación Educativa, 16(71), 61- 80 .

Johnson, L.A., Estrada, V., y Freeman, A. (2014). NMC Horizon Report: 2014 Higher Education Edition. Texas: The New Media Consortium.

Juan-Carvajal, D.T. y Juan-Carvajal, M.L. (2019). IniciARTE. Un acercamiento a la investigación científica. España: IMD.

Juan-Carvajal, M.L., y Juan-Carvajal, D. . (2014). Cuerdas frotadas en Cuba. Medio siglo de creación. Cuba: CIDMUC.

Sánchez, M.J., Juan-Carvajal, M.L., Vdovina, M., y Juan-Carvajal, D.T. (octubre-diciembre de 2016). Arte y ciencia, un debate inconcluso. ECORFAN. Revista Investigaciones Sociales, 2(6), 94-106.

Vdovina, M. (2010). La interpretación como proceso de creación. En G.J. Castillo (Coord.), Colorama musical: nuevos problemas, nuevas perspectivas (pp. 57-80). Zacatecas: Plaza y Valdés, S.A. de C.V. 